\title{
CITRA PEREMPUAN \\ PADA CERPEN SEPASANG MATA YANG TERPENJARA DAN PEREMPUAN ITU PERNAH CANTIK
}

\author{
Harum Ika Praningrum \\ Universitas Sebelas Maret \\ harum.ika.hip@gmail.com
}

\begin{abstract}
ABSTRAK
Penelitian ini berusaha membandingkan dua cerpen yang berjudul Sepasang Mata Dinaya yang Terpenjara (SMDYT) karya Ni Komang Ariani dan Perempuan Itu Pernah Cantik (PIPC) karya Mashdar Zainal. Pendekatan yang digunakan dalam penelitian ini adalah sastra bandingan dan kritik sastra feminis. Penelitian ini dilakukan dengan tahapan-tahapan yaitu (1) penetapan objek penelitian, (2) pengumpulan data yang akan dianalisis, (3) analisis data, (4) penyajian hasil analisis data. Setelah dibandingkan kedua cerpen ini memiliki kesamaan dalam hal bentuk ketidakadilan gender yang dialami oleh masing-masing tokoh utama dari dua cerpen tersebut. Bentuk-bentuk ketidakadilan gender tersebut adalah marginalisasi, stereotip, dan beban kerja ganda. Adapun perbedaan dua cerpen tersebut adalah kehadiran tokoh ibu dalam SMDYT dan tidak hadirnya sosok ibu dalam PIPC, perbedaan penggambaran watak tokoh suami, dan perbedaan sikap dalam menerima peran sebagai seorang istri dalam konteks tradisional.
\end{abstract}

Kata Kunci: sastra bandingan, citra perempuan, cerpen

ABSTRACT

This research attempts to compare two short stories entitled Sepasang Mata Dinaya Yang Terpenjara (SMDYT) by Ni Komang Ariani and Perempuan Itu Pernah Cantik (PIPC) by Mashdar Zainal. The approach used is the comparative literature and feminist literary criticism. This research is conducted in several stages, namely (1) determining the object of research, (2) collecting data to be analyzed, (3) analyzing the data, (4) presenting the results of the data analysis. After comparing the two short stories, they have similarities in terms of the form of gender injustice experienced by each of the main characters of the two short stories. The forms of gender injustice are marginalization, stereotypes, and double workloads. The differences between the two short stories are the presence of a mother figure in SMDYT and the absence of a mother figure in PIPC, the differences in the representation of the husband's character, and differences of attitudes in accepting the role of a wife in a traditional context.

Keywords: comparative literature, image of woman, short story

PENDAHULUAN

Cerpen adalah salah satu jenis prosa fiktif yang terdiri dari satu konflik. Prosa jenis ini biasanya selesai dibaca sekali duduk. Cerpen menjadi salah satu karya sastra yang dapat ditemukan pada koran-koran mingguan. Bentuknya yang singkat dan padat membuatnya terkesan 
lebih keras, lebih galak, dan lebih menekan daripada bentuk fiksi lainnya (Chudori, 2009). Sebagaimana karya sastra pada umumnya, cerpen menjadi salah satu bentuk representasi atau cermin sosial paling sederhana. Melalui cerpen berbagai topik dan permasalahan sosial diangkat oleh penulis. Salah satu topik yang menarik perhatian adalah permasalahan perempuan.

Perempuan kerap kali dijadikan objek dalam karya sastra. Permasalahan perempuan yang seakan tak pernah ada habisnya sangat menarik untuk dibicarakan. Tak jarang melalui karya sastra perempuan dieksploitasi sedemikian rupa. Perempuan dikonstruksikan memiliki sifat lemah lembut, irasional, emosional, tidak berdaya sehingga posisinya selalu berada di bawah laki-laki yang dicitrakan kuat, rasional, dan tegas. Menurut Miyasari (2019) berbagai fenomena gender dan perempuan menjadi faktor pendorong bagi pengarang untuk menghadirkannya dalam sebuah karya sastra. Hadirnya ideologi feminisme menjadi angin segar sekaligus menantang status quo kepatriarkatan yang selama ini mengakar kuat dalam budaya masyarakat. Feminisme memberikan perhatian pada jenis kelamin sebagai suatu prinsip pengatur kehidupan sosial yang secara menyeluruh oleh relasi kekuasaan yang menyubordinasikan perempuan di bawah laki-laki (Barker, 2000:177).

Cerpen Sepasang Mata Dinaya yang Terpenjara karya Ni Komang Ariani dan Perempuan Itu Pernah Cantik karya Mashdar Zainal merupakan dua contoh dari berbagai cerpen yang mengangkat permasalahan perempuan ke permukaan. Kedua cerpen tersebut samasama menggambarkan kehidupan seorang wanita dalam kehidupan rumah tangga dan bagaimana para tokoh perempuannya merasa terpenjara dalam hubungan tersebut. Dua cerpen ini menggambarkan bagaimana kedudukan dan posisi perempuan sebagai istri dan ibu rumah tangga. Dalam cerpen Sepasang Mata yang Terpenjara tokoh utamanya bernama Dinaya, ia merupakan seorang dosen yang dipaksa berhenti kerja setelah menikah. Sedangkan, dalam cerpen Perempuan Itu Pernah Cantik, tokoh perempuan dalam cerpen ini merupakan mantan peragawati yang kini disibukkan dengan pekerjaan rumah dan mengurus anak. Pada cerpen pertama tokoh Dinaya digambarkan sebagai perempuan yang cerdas dan berpendidikan, ia menunjukkan penolakan terhadap nilai-nilai yang menempatkan perempuan berada di bawah laki-laki. Cerpen kedua cerita berfokus pada pergolakan batin tokoh perempuan yang merindukan dirinya yang dulu pernah cantik sebagai peragawati.

Menurut Kurniati (2014) permasalahan perempuan yang menarik untuk dibicarakan ternyata juga menggelitik pengarang untuk menuangkannya ke dalam karya sastra. Dengan demikian, karya sastra yang merepresentasikan adanya fenomena keperempuanan harus diungkap dan dijelaskan kepada masyarakat. Berangkat dari hal tersebut, penulis tertarik untuk meneliti cerpen Sepasang Mata Dinaya yang Terpenjara dan Perempuan Itu Pernah Cantik dengan membandingkan kedua cerpen tersebut untuk kemudian dianalisis persamaan unsur-unsur ketidakadilan gender yang dialami oleh masingmasing tokoh dari dua cerpen tersebut. Melalui penelitian ini penulis ingin mengetahui bentuk-bentuk ketidakadilan gender yang dialami oleh tokoh perempuan dalam dua cerpen tersebut dan citra sosial 
mereka sebagai seorang istri.

Di dalam penelitian ini digunakan dua teori, yaitu teori sastra bandingan dan teori kritik sastra feminis. Teori sastra bandingan digunakan untuk membandingkan kedua cerpen-Sepasang Mata yang Terpenjara dan Perempuan Itu Pernah Cantik-guna mencari persamaan dan perbedaan diantaranya keduanya. Sedangkan, teori kritik sastra feminis digunakan untuk menganalisis bentuk-bentuk ketidakadilan gender yang ditemukan dalam dua cerpen tersebut. Sapardi menyatakan bahwa sastra bandingan bukan sekadar mempertentangkan dua sastra dari dua negara yang berbeda bahasa tetapi merupakan suatu metode untuk memperluas pendekatan atas sastra suatu bangsa saja. Batasan tersebut menunjukkan bahwa perbandingan tidak hanya terbatas pada sastra antarbangsa, tetapi juga sesama bangsa sendiri (Damono, 2009: 5-6). Di sisi lain, menurut Djajanegara (dalam Ambarwati, 2005: 13) kritik sastra feminis berangkat dari keinginan para feminis untuk mengkaji karya penulis perempuan dan untuk mewujudkan citra perempuan dalam karya sastra penulis pria yang menampilkan perempuan sebagai makhluk yang ditekan, disalahtafsirkan, dan disepelekan oleh tradisi patriakal yang dominan. Dalam penelitian ini cerpen Sepasang Mata yang Terpenjara merupakan karya seorang penulis perempuan, sedangkan Perempuan itu Pernah Cantik merupakan karya yang ditulis oleh penulis laki-laki. Penelitian ini secara spesifik menggunakan teori ketidakadilan gender yang dikemukakan oleh Mansour Fakih. Mansour Fakih menyebutkan terdapat ketidakadilan peran yang dialami oleh perempuan. Ketidakadilan peran ini dikonstruksi, disosialisasikan, diperkuat secara sosial dan kultural melalui ajaran agama maupun negara. (Fakih dalam Miyasari, 2019: 29). Ketidakadilan ini kemudian termanifestasikan dalam berbagai bentuk yaitu, marginalisasi (peminggiran atau pemiskinan ekonomi), subordinasi (penomorduaan), stereotip (citra baku), kekerasan, dan beban kerja ganda.

METODE

Penelitian ini berjenis kualitatif deskriptif. Objek material dari penelitian ini adalah cerpen Sepasang Mata Dinaya yang Terpenjara dan Perempuan Itu Pernah Cantik, adapun objek formalnya ialah bentuk-bentuk ketidakadilan gender dalam dua cerpen tersebut. Data dikumpulkan dengan menggunakan teknik simak dan teknik catat. Pendekatan sastra bandingan dan kritik sastra feminis digunakan sebagai pisau analisis untuk membandingkan objek tersebut. Pembandingan dua cerpen tersebut dilakukan untuk melihat unsur ketidakadilan gender yang dialami oleh tokoh perempuan pada masingmasing cerita. Adapun tahapan-tahapan penelitian ini adalah (1) penetapan objek penelitian, (2) pengumpulan data yang akan di analisis, (3) analisis data, (4) penyajian hasil analisis data.

\section{PEMBAHASAN Ketidakdilan Gender}

Ruthven (1984:40 - 50) menyatakan bahwa kritik sastra feminis merupakan kritik yang menelusuri bagaimana kaum perempuan direpresentasikan, bagaimanakah teks terwujud melalui relasi gender dan perbedaan sosial. Sebagaimana diungkapkan pada bagian sebelumnya perempuan sebagai makhluk sosial kerap dipandang rendah 
kedudukannya daripada laki-laki. Anggapan ini membuat perempuan mengalami ketidakadilan gender dalam berbagai lingkup seperti keluarga, sekolah, tempat kerja, dan lingkungan sosial. Ketidakadilan gender menurut Fakih (dalam Miyasari, 2019: 29) terbagi menjadi lima bentuk yakni marginalisasi, subordinasi, stereotip, kekerasan, dan beban kerja ganda. Cerpen Sepasang Mata Dinaya yang Terpenjara karya Ni Komang Ariani dan Perempuan Itu Pernah Cantik karya Mashdar Zainal merepresentasikan adanya ketidakadilan gender yang dialami oleh perempuan. Ketidakadilan gender yang dialami oleh tokoh Dinaya dan tokoh yang disebut sebagai perempuan itu adalah sebagai berikut.

\section{Marginalisasi}

Marginalisasi adalah usaha pembatasan ruang gerak wanita khusus ke dalam urusan domestik. Terdapat anggapan dalam masyarakat bahwa seorang wanita harus memenuhi kodratnya untuk tetap di rumah dan mengurusi urusan rumah mulai dari sumur, kasur, dan dapur. Konstruksi ini tidak hanya lahir atau diterapkan ketika seorang wanita sudah menikah melainkan sejak kecil. Lingkup keluarga menjadi lingkup dasar dibangunnya konstruksi ini.

Dalam cerpen Sepasang Mata Dinaya yang Terpenjara (selanjutnya disingkat SMDYT) proses marginalisasi yang dialami oleh tokoh Dinaya terlihat ketika Dinaya yang merupakan seorang dosen diminta oleh suami untuk berhenti dari pekerjaannya tersebut. Hal ini diungkapkan oleh tokoh Biyang.

"Bli Gusti yang tidak pernah menghargaiku sebagai perempuan. Mengapa aku tidak boleh mengembarakan pikiranku? Apa yang dia inginkan dari aku?"

"Dia ingin kamu lebih banyak di rumah untuk menemaninya, bukannya sibuk dengan urusanmu di kampus. Lagi pula pekerjaan rumah jadi terbengkalai. Urusan mebanten saja harus minta tolong orang lain. Bukankah seorang istri yang seharusnya mengerjakan semua itu?” (Kompas, 2010).

Dinaya merupakan seorang wanita berpendidikan yang cerdas dan sadar akan hak-haknya sebagai seorang perempuan. Namun, konstruksi budaya yang menempatkan wanita sebagai kanca wingking nampaknya telah mengakar kuat dalam budaya Bali yang kemudian membuatnya tidak berdaya. Dalam cerpen tersebut, Dinaya tidak diberi kesempatan untuk memilih, permintaan suaminya adalah kewajiban yang mutlak harus dilaksanakan, jika tidak Biyang mengancam bahwa Dinaya bukan lagi merupakan bagian dari keluarganya.

Hal serupa juga dialami oleh perempuan itu atau ia dalam cerpen Perempuan Itu Pernah Cantik (selanjutnya disingkat PIPC). Tokoh ia dulunya merupakan seorang peragawati, ia tiga kali memenangkan kontes kecantikan. Namun prestasi dan kebanggaannya tersebut seakan lenyap ketika ia menikah. Tokoh ia harus menghadapi kenyataan bahwa menjadi berprestasi sebagai seorang perempuan tidak bermakna apa pun. Pada akhirnya ia akan kembali memenuhi kodratnya sebagai seorang wanita untuk mengurusi rumah. 
Orang mungkin tak 'kan percaya bahwa di masa muda ia pernah menjuarai kontes kecantikan tingkat kota. Tepatnya tiga kali. Ia diundang ke hotel bintang lima berbaur dengan modelmodel lain dari berbagai kota. Melenggang di atas panggung. Mempertontonkan kecerdasan serta kecantikan luar dalam (JawaPos.com, 2019)

Berbeda dengan kehidupannya dahulu, tokoh ia kini saban hari harus berurusan dengan cucian baju dan cucian piring yang menggunung. Kewajibannya untuk memasakkan suami, mengurus anak, dan melayaninya setiap malam.

Tokoh Dinaya dan tokoh ia merupakan wanita modern yang berpendidikan dan berprestasi. Namun budaya patriarki yang mengakar kuat tetap menyeret mereka untuk memenuhi kodratnya sebagai seorang perempuan, yakni untuk mengurusi dapur, sumur dan kasur. Perbedaan dari kedua teks ini terletak pada latar belakang budaya. Cerpen SMDYT berlatar belakang budaya Bali karena penulisnya merupakan orang Bali, sedangkan cerpen Perempuan Itu Pernah Cantik berlatar belakang budaya Jawa.

\section{Stereotip}

Perempuan selalu lekat dengan stereotip atau pelabelan. Stereotip atau pelabelan tersebut berasal dari adat yang membakukan tentang bagaimana perempuan "seharusnya". Stereotip ini muncul tanpa memberi kesempatan kepada perempuan untuk "keluar" dari aturan yang ideal menurut adat dan tradisi. Bila berusaha "keluar" dari aturan tersebut mereka akan dicap sebagai perempuan yang menyalahi adat atau tidak dianggap sebagai wanita sejati. Stereotip terhadap perempuan muncul sebagai usaha mengekang perempuan agar tetap pada tempatnya untuk memuaskan seorang laki-laki.

Dalam cerpen SMDYT, pandangan bahwa sumber kebahagiaan perempuan diperoleh bila memuaskan kebutuhan lelaki kental dimiliki oleh Biyang. Orang tua Dinaya menyekolahkan Dinaya hingga menjadi sarjana namun mereka tidak menginginkan Dinaya menjadi lebih pintar dari mereka. Sekolah tinggi bagi orang tua Dinaya dianggap sebagai salah satu cara yang ditempuh untuk meningkatkan prestise keluarga secara umum dan Dinaya sebagai pribadi, bukan untuk menjadikan Dinaya sebagai perempuan intelek yang memiliki pemikiran terbuka dan memiliki kedalaman ilmu pengetahuan. Mereka menganggap bahwa perempuan cerdas sebagai perempuan yang tinggi hati.

Sejak kecil Biyang selalu mengata-ngatai Dinaya dengan kata-kata yang menghancurkan harga dirinya. Perempuan kok bangun siang. Makan kok belepotan seperti babi. Itu badan apa gentong air. Mana ada sih laki-laki yang mau melihat tampangmu. Sekali-kali ke salon dong biar tidak dikira babu. Di hadapan Biyang, Dinaya merasa menjadi manusia yang paling gagal (Kompas, 2010).

Kutipan di atas, menggambarkan stereotip bahwa perempuan harus rajin, rapi, dan cantik sudah diterapkan dalam lingkungan keluarga. Konstruksi inilah yang kemudian memunculkan ketakutan 
dalam diri Dinaya jika kelak dirinya menjadi perawan tua. Ketakutan tersebut membuat ia bersembunyi dibalik hubungan pernikahan yang tak ia inginkan. Ia menikah dengan suami yang tidak dicintainya yaitu Gusti Nyoman Ghana melalui perjodohan.

Hal serupa juga dialami tokoh ia dalam PIPC. Ia menjalani segala pelabelan tentang bagaimana wanita 'seharusnya' dengan penuh tekanan. Ia berkali-kali berkaca di depan cermin hanya untuk meyakinkan dirinya sendiri bahwa dulu ia pernah cantik. Beban sebagai ibu rumah tangga dan himpitan ekonomi telah membuat ia kehilangan guratan kecantikan yang dahulu ia banggakan.

Maka, jika ia sangat lelah, dan balitanya tak henti-henti membuat ulah, ia akan berlari ke kamar mandi. Mencelupkan segenap kepalanya ke dalam air dan berteriak sekencangkencangnya. Rambutnya basah. Dasternya basah. Napasnya megap-megap. Dan ia tak pernah peduli. Seolah sangat tidak masalah kalau daster basah itu akan membuatnya kedinginan, lalu membuatnya sakit, lalu membuatnya mati (JawaPos.com, 2019).

Meski sama-sama merupakan seorang istri, terdapat perbedaan nasib antara tokoh Dinaya dalam SMDYT dan tokoh ia dalam PIPC. Memiliki kewajiban yang sama sebagai seorang istri Dinaya lebih beruntung secara ekonomi. Sebab dulu dirinya merupakan seorang dosen, dan suaminya adalah seorang pegawai negeri. Di Indonesia, pekerjaan sebagai pegawai negeri termasuk pekerjaan yang mentereng dan dihormati oleh masyarakat. Sedangkan tokoh ia kurang beruntung secara ekonomi karena suaminya hanyalah seorang pegawai asuransi yang kerap lembur hingga tak punya begitu banyak waktu di rumah.

\section{Beban Kerja Ganda}

Adanya pembedaan antara maskulinitas dan feminitas telah melahirkan pembedaan pekerjaan antara pria dan wanita. Dalam kehidupan rumah tangga, pria menduduki posisi sebagai kepala rumah tangga yang mana tugas dan kewajibannya adalah mencari nafkah. Sedangkan perempuan, sebagai istri memiliki tugas untuk mengurus segala urusan rumah tangga, mulai dari kebersihan rumah, mengurus anak, hingga melayani suami. Jika dicermati terdapat ketimpangan antara beban pekerjaan suami dan istri. Dalam kehidupan rumah tangga, perempuan mendapat beban kerja ganda sebagai akibat dari posisinya sebagai istri dan juga ibu.

Dalam cerpen SMDYT, setelah berhenti dari pekerjaannya sebagai seorang dosen. Dinaya menjalani segala kewajibannya sebagai seorang istri yang harus memenuhi segala kebutuhan suami.

Hari-hari berikutnya Dinaya memusatkan perhatiannya pada setumpuk pekerjaan rumah tangga yang harus dikerjakannya. Dinaya bangun subuh dan mulai menyiapkan masakan di dapur dan menyapu halaman rumah yang penuh dengan dedaunan layu. Tepat jam tujuh pagi ia menyiapkan kopi untuk suaminya.

......Dan ia pun harus menyediakan waktunya dari subuh hingga malam hari untuk mengosongkan seluruh energi yang 
dimilikinya. Semua pekerjaan yang tiada habisnya itu akan menghampakan dia sehingga tidak akan pernah ada ruang untuk berpikir (Kompas, 2010).

Hal ini berbanding terbalik dengan kegiatan suaminya di rumah. Berbeda dengan Dinaya yang harus bangun sejak subuh untuk menyiapkan sarapan dan bersih-bersih rumah. Suaminya, Ghana setiap pagi pekerjaannya hanyalah minum kopi dan membicarakan pekerjaannya sendiri. Di sela waktunya di rumah ia terkadang sibuk bermain plays station-nya.

Beban pekerjaan yang banyak juga dialami oleh tokoh ia dalam PIPC. Tokoh ia sering sekali merasa kelelahan secara fisik apalagi mental tatkala harus dihadapkan dengan seabrek pekerjaan rumah dan kewajibannya mengurus anak yang masih balita.

Kalau sedang jengkel, ia akan menyeret bak cuci berisi pakaian basah itu dari kamar mandi sampai ke bawah pohon mangga. Tak peduli bak plastik itu akan retak atau terbelah dua. Suatu kali itu pernah terjadi. Menyeret bak cuci itu sampai terbelah hingga cucian-cucian yang sudah dibilas itu berbaur dengan tanah. Ia tak memunguti baju-baju yang kembali menjadi kotor itu, alih-alih mengilas-ilasnya di tempat lantaran jengkel. Membuat baju-baju itu berlepotan tanah.

Kejengkelan dan rasa lelah yang sangat membuatnya jadi begitu (JawaPos.com, 2019).

Perbedaan lainnya dari dua cerpen ini ialah hadirnya sosok ibu dalam SMDYT. Sosok ibu dalam cerpen SMDYT menjadi semacam otoritas yang melanggengkan perintah suami untuk dituruti. Sosok ibu tidak hadir atau disinggung dalam cerpen PIPC. Perbedaan lainnya adalah penggambaran sosok suami. Dalam SMDYT, sosok suami digambarkan sebagai seorang yang sewenang-wenang dan memiliki kekuasaan yang mendominasi. Dalam PIPC, sosok suami tidak digambarkan begitu jelas. Cerita dalam cerpen ini fokus menyoroti pergolakan mental tokoh ia sebagai seorang istri. Tokoh suami hanya dimunculkan sekilas pada bagian akhir. Tokoh suami dalam PIPC digambarkan sebagai orang yang turut lelah secara mental dan fisik akibat dari pekerjaan kantornya yang hampir-hampir tidak mengenal hari libur.

\section{Citra Perempuan sebagai Seorang Istri}

Menurut Kurniati (2014) Perkawinan adalah ikatan sosial atau ikatan perjanjian hukum antar pribadi yang membentuk hubungan kekerabatan dan yang merupakan suatu pranata dalam budaya setempat yang meresmikan hubungan antar pribadi yang biasanya intim dan seksual. Laki-laki yang telah diikat pernikahan disebut sebagai suami dan perempuan yang telah diikat dengan perkawinan disebut sebagai istri. Dalam kehidupan pernikahan, suami memegang peranan sebagai kepala rumah tangga yang bertugas untuk memenuh nafkah mulai dari sandang, pangan, dan papan. Sedangkan konsep perempuan sebagai istri adalah untuk menjaga kehidupan rumah tangga tentram dan damai. Dalam konteks ini, perempuan harus memiliki sifat baik untuk dapat 
menyenangkan suami, menaati perintah suami, dan menjaga martabat keluarganya.

Citra perempuan sebagai seorang istri diungkapkan melalui tokoh utama dalam cerita seperti Dinaya dalam SMDYT dan tokoh ia dalam PIPC. Kedua tokoh tersebut mencitrakan perempuan sebagai seorang istri dalam konteks yang tradisional. Hal ini dapat dilihat dari ruang gerak mereka yang terbatas pada lingkup domestik saja. Pembatasan gerak seorang istri dapat dilihat dalam cerpen SMDYT yang mana seorang suami memiliki otoritas untuk melarang sang istri bekerja. Seorang istri yang baik digambarkan sebagai seseorang yang selalu tunduk dan patuh pada perintah suami. Tak hanya itu, menjadi seorang istri berarti merelakan segala kehendak diri untuk kemudian mengabdi pada suami dan kehidupan rumah tangga. Hal ini dapat dilihat dalam dua cerpen tersebut, bagaimana Dinaya meninggalkan pendidikan dan pekerjaan tetapnya sebagai seorang dosen dan juga bagaimana tokoh ia merelakan segala prestasi dan kecantikannya untuk mengabdi sebagai istri yang harus mengurus rumah tangga dan juga mengurus anak.

Sebagai seorang istri, tokoh Dinaya digambarkan sebagai orang yang kritis. Ia mengerti tentang apa yang menjadi hak-haknya. Ia digambarkan sebagai seorang wanita yang berani menunjukkan ketidaksetujuannya terhadap nilai-nilai yang dirasa terlalu mengekang perempuan sebagai seorang istri. Hal tersebut dibuktikan dalam percakapannya dengan Biyang ketika ia berusaha menolak permintaan suaminya untuk berhenti bekerja. Ketidaksetujuan Dinaya terhadap nilai-nilai bagaimana menjadi seorang istri yang diajarkan oleh Biyangnya ditunjukkan dalam kalimat di bawah ini.

"Baiklah tiang menuruti Biyang sekarang, tapi bukan karena tiang merasa Biyang benar. Tiang akan berhenti bekerja, tapi jangan harap tiang akan menghormati Bli Gusti. Pernikahan ini memang masih ada, tapi bagi tiang ini bukan pernikahan tiang. Tiang sudah mati dalam pernikahan ini. Yang tinggal hanya raga tiang." (Kompas, 2010).

Melalui kutipan di atas, tokoh Dinaya menyatakan ketidaksetujuannya terhadap perintah Biyang. Namun di satu sisi juga menunjukkan ketidakberdayaannya sebagai seorang wanita. Tokoh Dinaya dalam cerpen tersebut digambarkan meskipun ia tidak menyetujui perintah dan kehendak Biyang dan Bli Gusti namun ia tidak memiliki pilihan lain selain tunduk terhadap perintah tersebut. Hal yang menarik dalam diri tokoh Dinaya adalah ia berhenti bekerja dan menuruti perintah suami bukan karena ia merasa hal tersebut benar melainkan hanya untuk meredam konflik internal dalam keluarga.

Dalam PIPC, tokoh ia tidak melakukan perlawanan atau konfrontasi secara langsung terhadap segala beban kerja dan kewajiban yang ia alami. Dibanding menyebutnya sebagai perlawanan, cerpen PIPC lebih menyoroti pergolakan batin seorang istri yang seolah terjebak dalam dunia domestik untuk mengurus rumah tangga dan anak. Dalam hal ini tokoh ia digambarkan sebagai seorang istri pada umumnya yang mengalami kelelahan secara fisik akibat banyaknya pekerjaan rumah tangga, dan kelelahannya secara mental karena 
ketidakmampuannya mengungkapkan atau mengejawantahkan segala beban yang ia tanggung. Berbeda dengan Dinaya yang memandang pernikahannya sebagai penjara yang membelenggunya dari kebebasan berpikir yang membuatnya menyimpan kebencian terhadap suaminya, tokoh ia meski ia mengalami beban yang hampir sama tetap menaruh hormat dan cinta kepada suaminya. Hal ini ditunjukkan pada kutipan berikut.

Di sela hari-hari yang berat dan melelahkan, detik itulah yang paling indah dan paling ia nanti. Ketika suami dan anaknya tertidur (JawaPos.com, 2019).

\section{Citra Perempuan dalam Budaya Bali dan Jawa}

Dalam budaya Bali dan Jawa perempuan memiliki posisi yang hampir sama. Dua kebudayaan tersebut menganut sistem patriarki yang menempatkan perempuan berada di bawah laki-laki dan memojokkan peran mereka hanya wilayah domestik dan reproduksi saja. Sistem patriarki yang berkembang di masyarakat Bali menggariskan bahwa yang menjadi tolok ukur garis keturunan adalah laki-laki. Hal ini memiliki dampak yang cukup kompleks. Salah satunya bentuknya adalah sistem kekerabatan di Bali yang patrilineal. Konstruksi budaya tersebut menempatkan laki-laki menjadi otoritas utama atau sentral dalam segala aspek kehidupan dibandingkan perempuan. Hal ini terlihat jelas dalam cerpen Sepasang Mata Dinaya yang Terpenjara. Bli Gusti dalam cerita tersebut memiliki otoritas penuh dalam rumah tangganya untuk melarang sang istri bekerja tanpa mendengar opini atau tanggapan dari istrinya. Tidak hanya itu, otoritas tersebut juga turut dibenarkan oleh Biyang, ibu dari Dinaya yang turut mengancam Dinaya agar sang anak tunduk pada perintah suaminya tersebut.

Serupa dengan budaya Bali, sistem patriarki di Jawa juga masih mengakar kuat. Meski tak dapat dipungkiri bahwa dewasa ini kaum perempuan Jawa telah sadar akan pentingnya kesetaraan gender. Dalam budaya Jawa terdapat konsep tentang perempuan sejati yang selalu dihubungkan dengan bentuk tubuh dan kodrat alami perempuan. Dalam kehidupan pernikahan, tugas perempuan terbatas pada tiga sektor yaitu masak (memasak), manak (melahirkan), macak (berdandan). Hal ini digambarkan dengan jelas dalam cerpen Perempuan Itu Pernah Cantik, di mana tokoh perempuan dalam cerpen tersebut selalu disibukkan dengan pekerjaan rumah tangga dan mengurus anak. Adanya sistem patriarki telah merugikan kaum perempuan. Nilai-nilai yang diajarkan tentang bagaimana perempuan 'seharusnya' telah membuat perempuan merasa sulit untuk berkembang sebagai pribadi dan juga menemukan jati dirinya. Hal ini tergambar jelas melalui pergolakan batin tokoh perempuan dalam cerpen PIPC. Kehidupan ekonomi yang pas-pasan, kewajiban mengurus anak dan rumah seolah mengungkung perempuan $i t u$ dalam situasi yang tidak diinginkan dan membuatnya kehilangan jati diri. Sehingga dalam cerpen tersebut tokoh perempuan itu digambarkan merindukan dirinya yang dulu, sebelum ia menikah dan masih menjadi peragawati.

Pernikahan dalam budaya Bali dan Jawa dianggap sebagai sesuatu yang sangat penting. Perempuan di Bali maupun Jawa yang tidak segera menikah biasanya akan disebut sebagai perawan tua. Anak 
gadis yang sudah cukup umur dan belum menikah dipandang sebagai sesuatu yang kurang baik dan menjadi beban bagi keluarga. Salah satu hal yang membedakan budaya Bali dan Jawa dalam hal pernikahan adalah sistem kasta. Sistem ini berkembang di Bali erat kaitannya dengan agama Hindu. Dalam budaya Bali pernikahan sebisa mungkin dilaksanakan sederajat dalam adat, agama, dan kasta. Hal ini bertujuan untuk menjaga kemurnian kasta. Dalam cerpen SMDYT, tokoh Dinaya dan Bli Gusti berada dalam kasta yang sama hal ini dapat dilihat dari latar belakang keluarga dan pendidikan dari kedua tokoh tersebut. Bli Gusti adalah lelaki yang dipilihkan oleh orang tua untuk menjadi suami Dinaya.

Dalam budaya Jawa tidak dikenal adanya kasta, namun dalam hal mencari pasangan dikenal istilah bibit, bebet, bobot. Bibit mempersoalkan asal-usul atau keturunan, bebet mempersoalkan status ekonomi seseorang, dan bobot mempersoalkan kualitas diri seseorang. Pandangan mengenai bibit, bebet, bobot ini biasanya akan menjadi pertimbangan bagi masing-masing orang tua yang hendak menikahkan anaknya. Dalam cerpen PIPC hal ini tidak digambarkan. Berbeda dengan cerpen SMDYT yang menggambarkan status sosial, ekonomi hingga kasta dari masing-masing tokoh, Dinaya dan Bli Gusti. Cerpen PIPC hanya menggambarkan kondisi ekonomi dari keluarga tokoh perempuan itu tanpa lebih jauh menyinggung soal status sosial dan asal usul keluarga dari tokoh perempuan itu maupun suaminya.

\section{SIMPULAN}

Cerpen Sepasang Mata Dinaya yang Terpenjara dan Perempuan Itu Pernah Cantik mengangkat tema yang sama yaitu tentang permasalahan yang sering dialami perempuan dalam kehidupan rumah tangga. Kedua cerpen tersebut menunjukkan adanya kesamaan dalam hal ketidakadilan gender yang dialami oleh para tokoh utamanya. Bentuk-bentuk ketidakadilan gender tersebut antara lain adalah marginalisasi, stereotip, dan beban kerja ganda. Perbedaan dari dua cerpen tersebut terlihat pada beberapa hal seperti hadirnya tokoh ibu dalam SMDYT yang mana hal tersebut tidak ada dalam cerpen PIPC, perbedaan penggambaran watak tokoh seorang suami, dan perbedaan sikap tokoh Dinaya dan tokoh ia dalam menerima perannya sebagai istri dalam konteks tradisional. Tokoh Dinaya cenderung menunjukkan penolakan terhadap pandangan tradisional peran seorang istri sedangkan tokoh ia menunjukkan penerimaan namun ia kerap merindukan dirinya yang dulu. Perbedaan tersebut sangat mungkin terjadi sebagai akibat dari perbedaan gender penulisnya. Cerpen SMDYT ditulis dari sudut pandang perempuan oleh seorang perempuan, sedangkan PIPC ditulis dari sudut pandang perempuan oleh seorang laki-laki. Selain itu, dalam budaya Bali dan Jawa menganut sistem patriarki yang merugikan posisi perempuan. Perempuan dalam budaya Bali dan Jawa memiliki kesamaan peran dalam rumah tangga yakni terbatas pada sektor domestik dan reproduksi.

\section{DAFTAR PUSTAKA}

Ambarwati, Sri. 2005. "Ketimpangan Gender Budaya Bali dalam Novelet Perempuan-Perempuan Matahari Karya Oka Rusmini: Sebuah
Pendekatan Feminis". Skripsi. Fakultas Sastra dan Seni Rupa, Sastra Indonesia, Universitas Sebelas Maret, Surakarta. 
Budiati, Atik Catur. 2010. Aktualisasi Diri Perempuan dalam Sistem Budaya Jawa (Persepsi Perempuan terhadap Nilai-nilai Budaya Jawa dalam Mengaktualisasikan Diri). Jurnal Pamator: Jurnal Ilmiah Universitas Trunojoyo. 3(1): 51-59.

Chudori, Laila S. 2009. Malam Terakhir. Jakarta: KGP.

http://cerpenkompas.wordpress.com/2010/0 5/30/sepasang-mata-dinayayang-terpenjara/amp/ Diakses pada tanggal 14 Desember 2020

http://www.jawapos.com/minggu/cerpen/28 /07/2019/perempuan-itupernah-cantik $/ 30 \% 3$ famp

Diakses pada tanggal 14 Desember 2020

http://www.widiadiantari.com/2019/01/men jadi-perempuan-bali-itu-berat.html. 2019. "Menjadi Perempuan Bali Itu, Berat". 7 Januari.

Juanda dan Aziz. 2018. Penyingkapan Citra Perempuan Cerpen Media Indonesia: Kajian Feminisme. Jurnal Lingua. 15(2): 71-82.

Kurniati, Chrisna Putri. 2014. Citra Perempuan dalam Novel Burung Tiung Seri Gading Karya Hasan Junus. Jurnal Madah: Jurnal Bahasa dan Sastra. 5(2): 157-170.

Miyasari, Tita Nurajeng. 2019. Ketidakadilan Gender dalam Novel Gadis Pantai karya Pramoedya Ananta Toer dan Tanah Tabu Karya Anindita S. Thayf: Kajian Sastra Bandingan. Jurnal Alaya Sastra. 15(1): 24-44. 